\title{
SIX SIGMA PRACTICES ON THE PERCEIVED BETTERMENT OF ORGANIZATION PERFORMANCE
}

\author{
Taimoor Ahmed Siddiqui ${ }^{1}$ and Muhammad Ali Iqbal ${ }^{2}$
}

\begin{abstract}
Six Sigma has become a leading business improvement methodology which has been successfully applied in a wide range of businesses. In so doing, companies focus on systematically creating value and reducing and removing waste (the lean element of the approach) whilst employing Six Sigma to focus on and to eradicate the Critical to Quality (CTQ) issues that affect an organization. The research strategy of this paper is survey method and primary data was gathered from supply chain and quality enhancement departments of selected Six Sigma companies $n$ Karachi, Pakistan through structured questionnaires. This paper indicates that the performance of the company becomes highly reliable, reduced cost, eliminate wastages, and improve quality by the adaption of SixSigma practices. The study also reported that the continuous improvement is also playing a mediating role when we consider Company's performance as dependent variable and cost reduction, Quality betterment and eliminate wastages as independent variables.
\end{abstract}

Keywords: Waste Management, Six-Sigma, Organization Performance, Lean Management.

\section{INTRODUCTION}

Six-Sigma is a concept that originated from Motorola Inc.in the USA around 1985. At the time they were facing the threats of Japanese competition in the electronics industry and needed to

\footnotetext{
$1 \& 2$ Institute of Business Management, Karachi
} 
make drastic improvements in their quality levels. Six-Sigma has gained important attention in the academic and business field due to its financial impact and levels of customer satisfaction. Many scholars of different angles study Six-Sigma. However, they have argued that the effectiveness of Six-Sigma is undermined due to firms misunderstanding or its principles and risk related to its implementation (Muzaffer, Muhammad, \& Aihemaituoheti , 2016).The adoption of Six-Sigma through some popular companies and the year of invention with the name of inventor are 1777 - 1855 Carl Frederick Gauss introduced the concept of the normal curve, 1986 Six Sigma formulated by Bill Smith in Motorola, 1988 Motorola becomes the first company to win Malcolm Baldridge National Quality Award, 1993 Allied Signal adopted Six Sigma, 1995 General Electric (GE) launched the Six Sigma initiative, 1998 Honeywell adopted Six Sigma, 2000 Ford adopted Six Sigma (Quality Gurus, 2019). During the period of evolution that is from 1979-1986, Six Sigma had gone through several versions from RDMAICSI to DMAIC. Michel Harry and Bill Smith played a critical role in this period to evolve Six-Sigma technology (Grey , 2019)

\section{Introduction}

Six Sigma has become a leading business improvement methodology which has been successfully applied in a wide range of businesses. In so doing, companies focus on systematically creating value and reducing and removing waste (the lean element of the approach) whilst employing Six Sigma to focus on and to eradicate the Critical to Quality (CTQ) issues that affect an organization (Zhang, Wang, Goh, \& He, 2015). Six Sigma is a quality management system that focuses on the variance reduction leading to the design of business processes that produce approximately 3.4 defects per million opportunities. Although, Six Sigma tool has a specific role and is often narrow in focus, the Six Sigma technique has wider applications and requires specific skills, creativity and training than total quality management tools (Mason, Nicolay, \& Darzi, 2015). Six Sigma programs involve operational 
performance in order to enhance customer satisfaction with a company's products and services. Over the year many companies such as general electric, Allied signal, Raytheon and Delphi automotive have implemented Six-Sigma programs and claimed that these programs have transformed their organizations.(Nilesh, Bansod, \& Swati, 2012). Six Sigma, like other approaches to business improvement e.g., TQM and ISO 9000, has a strong customer focus and contains key concepts related to strategy, organizational change, training and setting stretch objectives (Evans \& Lindsay, 2008)

\section{Research Gap}

There is no single performance evaluation method that would be appropriate for all companies; the method should be chosen individually considering the aim of the evaluation and the needs of the company. There can be established a multi-criteria performance evaluation model that would satisfy the needs of a particular business' activity and targets for evaluation. So the further research can be targeted at establishing model like this for manufacturing companies by identifying a set of specific key performance indicators and their impact on performance results (Judita \& Aurelija , 2018)

\section{Statement of the Problem}

Due to an increasing pace and complexity of business environments, organizations no longer compete on processes but the ability to continually improve processes (Teece, 2007). At the same time numerous organizations that have deployed continuous improvement initiatives have not been successful in getting what they set out to achieve (Nilesh et. Al., 2012). This is what described in this research paper that how Six-Sigma practices along with the continuous improvement can contribute for perceiving betterment of performance of company because it is not necessary that a single model can be applied over all companies.

There is no single performance evaluation method that would be appropriate for all companies; the method should be chosen individually considering the aim of the evaluation and the needs 
of the company. There can be established a multi-criteria performance evaluation model that would satisfy the needs of a particular business' activity and targets for evaluation. So the further research can be targeted at establishing model like this for manufacturing companies by identifying a set of specific key performance indicators and their impact on performance results (Judita et al., 2018)

\section{THEORETICAL FRAMEWORK}

The objective to this section is to develop a research framework that can guide the experts towards perceiving betterment of company's performance through practices of Six-Sigma. An important measure of effectiveness of Six Sigma is the quality improvement because the Six Sigma, a quality improvement methodology based on statistics, is the latest method in a progression of integrated quality plan series, such as Quality Circle, TQM, Team Concept, and ISO9000 (Gluckman, 2003). Six Sigma can fulfill its role in improving the quality (Jones, 2004), which suggests the need to eliminate waste factors by accomplishing a nearly perfect quality level and this is one of the goals of Six Sigma (Kun-, Honglei, \& Bong, 2011). The importance of cost reduction while eliminating wastages and higher company performance was highlighted by (Heuvel, Does, \& Bisgaard, 2005) Cost can be reduced by eliminating waste, such as reducing errors or mistakes in a process or reducing the time taken to complete a task. A concrete example is to reduce a patient's stay at a hospital which can provide opportunity for more admissions. Although there are many practices associated with the Six-Sigma but the most important as according to the researchers have been taken in the paper as (Ayon \& Michael , 2013) endorsed about the importance that if problems are detected within process execution, continuous process improvement is implemented within line management and it is the part of company's performance improvement as a whole. Moreover, according to (Daniela \& Marly , 2016) Six Sigma projects are expected to lead improved operational performance, providing return on invested capital faster, with lower production costs, more efficiency in 
spending on research and development, development of new products with greater speed and meeting the expectations of its customers.

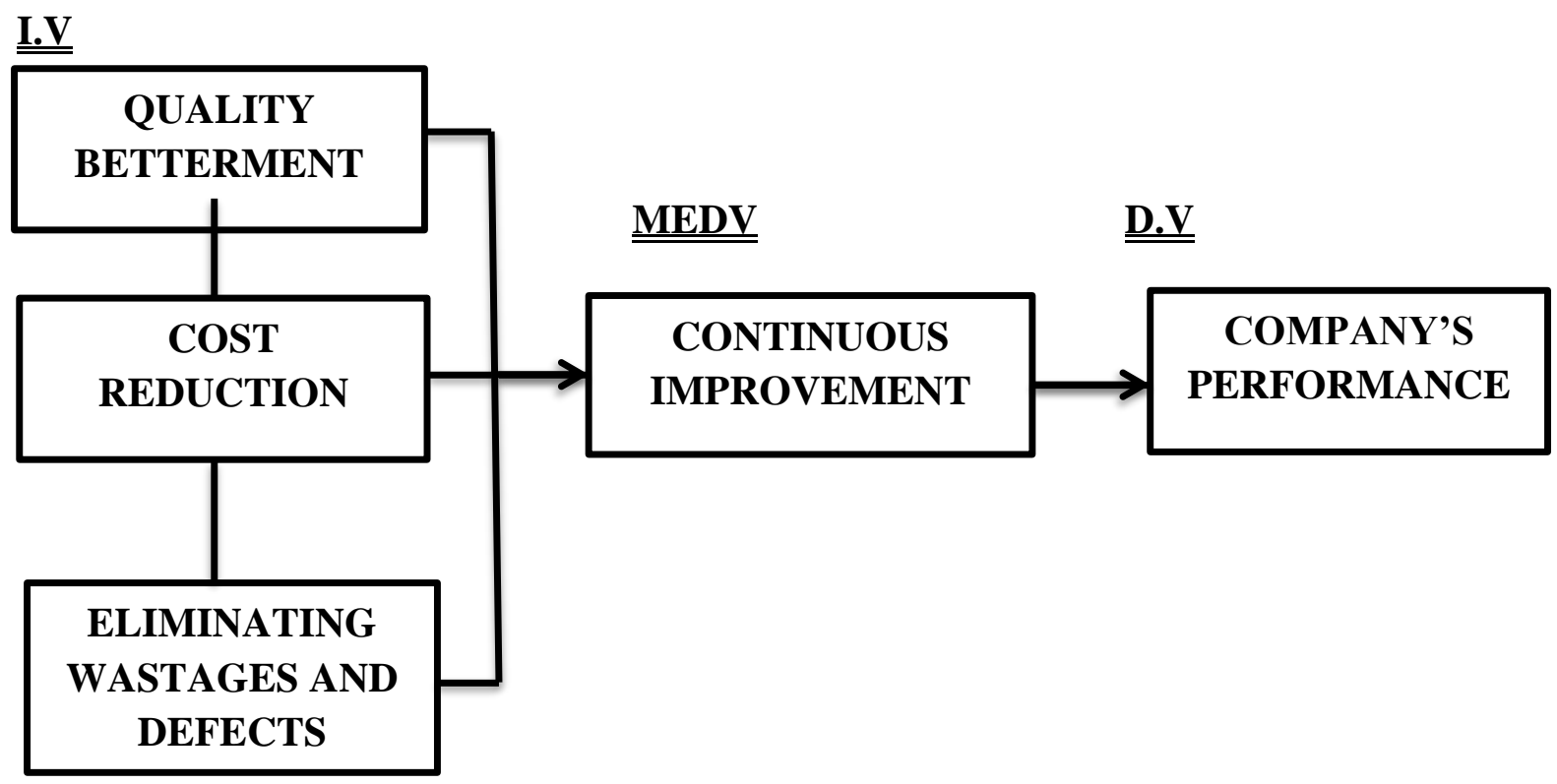

\section{HYPOTHESIS}

H1o. There is no effect of quality betterment on company's performance having continuous improvement as a mediator.

$\boldsymbol{H}_{1 A^{-}}$There is positive effect of quality betterment on company's performance having continuous improvement as mediator.

$\boldsymbol{H}_{20}$ - There is no effect of Cost Reduction on Company's performance having continuous improvement as mediator.

$\boldsymbol{H}_{2 A}$ - There is positive effect of Cost Reduction on Company's performance having continuous improvement as mediator.

$\boldsymbol{H}_{30}$ - There is no effect of Eliminating Wastages on company's performance having continuous improvement as mediator.

$\boldsymbol{H}_{3 A}$ - There is positive effect of Eliminating Wastages on company's performance having a continuous improvement as mediator. 


\section{SCOPE, SIGNIFICANCE AND PURPOSE OF RESEARCH}

Six Sigma provided an effective means to identify inefficient work processes that caused delays and hindrances in projects and could fix the problems in order to enhance the overall quality (Hassan, 2017). This study is useful for all those companies who are willing to increase their profit, betterment of quality, improvement of processes while eliminating the wastages and defects in their products and want to get their customers satisfied whether they are manufacturing, trading, services or any other sector. Moreover, the Six Sigma is an effective approach to a broad-based quality control program. According to (Basant, Dixit, \& Ashish , 2019) the scope should be broadened as more companies adopt quality and process improvement programs, such as LSS. Pearson (2019) stated that the Six Sigma is about starting out as a problem-solving process. The problems generally concerned eliminating variability, defects, and waste in a product or process, all of which undermine customer satisfaction. Six Sigma practitioners call this original method DMAIC (pronounced "duh-may-ick") - Design, Measure, Analyze, Improve, and Control. This is how it can be helpful for most of the companies but as mentioned in the research gap that it is not necessary that this approach fits for all. So, some other practices have been discussed in this research paper.

Six Sigma is more than a quality control program with the other name; it is a quality-based system for reorganizing the entire approach to work in every aspect: productivity, communication, involvement at every level and external services. Most significantly this research is related to the manufacturing sectors because they involve production, raw materials, checking and many more things. There are many critical steps in production of any manufacturing company and Six-Sigma lead us in every stage by maintaining the quality of product and eliminate wastages and cost cutting to get customer satisfaction with high profitability. The continuous improvement is a relationship between all the factors discussed in start of the significance with the performance of the company. Six Sigma provided an 
effective means to identify inefficient work processes that caused delays and hindrances in projects and could fix the problems in order to enhance the overall quality (SBF, 2013).

\section{LIMITATIONS \& DELIMITATIONS}

There are certain limitations to the study. One of them is those sectors where the behavior is autocratic; the data collection will be a problem because at most they do not want any change or betterment to their system. Limited trained/educated man power in subject of Six-Sigma and specific skill set of respondents is required to collect data. The problem for small and medium size enterprises as claimed by Chang (2002) is that it is difficult to follow the common training scheme of Six-Sigma (green belt, black belt etc.) by them because they have limited funds. The study utilized the quantitative approach for the collection of data by means of measuring the prevalence of Six Sigma practices on a scale and did not encompass a qualitative approach to provide extensive insights about the trends in Six Sigma (Hassan et. al., 2017).

This section concluded about the introduction of Six-Sigma practices with its background. The identified research gap has been discussed that how crucial is to implement a single model for every company, on the basis of which the problem statement is made which describes what this paper is going to answer and after that the framework for showing the importance of variables which have been researched to make literature review and hypothesis authentic. The limitations and delimitations clearly showing that where the hurdles are and to what extent the researcher may move whereas the significance, scope and purpose showing the how significant Six-Sigma practices are for perceiving betterment of company's performance and how much broader is the scope. The research will work to identify the causes for having work delays, lead time issues, non-availability of quality parameters, not focusing on continuous improvement because Six-Sigma is more than a traditional approach which focusing on the betterment of quality, reduction of cost, elimination of wastages and obviously on the continuous improvement. 


\section{LITERATURE REVIEW}

The continuous improvement is the need of every firm who need to enhance their profitability, customer satisfaction, having wastages next to none and to improve their process effectively and efficiently and that is what, Six-Sigma is all about.

The relationship of Quality betterment and company's performance with continuous improvement as mediator

The driving forces to the success of lean implementation include comprehensive training programme, teamwork and top management commitment (Piercy \& Rich, 2009). Lean aims to reduce human effort, stocks, delivery time and production space to meet the demands of the market while delivering high-quality products at the lowest price (Staatsa, Brunnerb, \& Upton, 2011). For any organization, the integration of continuous improvement methodologies and quality management systems (QMSs) to achieve total quality is necessary; a good exploitation of potential improvements and resources is among the prerequisites for this integration (Pfeifer, Reissiger, \& Canales, 2004).

A firm quality performance can be improved by minimizing the production defects (Prybutok \& Ramasesh, 2005). The quality of product means that it should be free of defects and at least it should fulfill the needs of the customer. So the observes result should at least match the desired result (Anand, Ward, Tatikonda, \& Schilling, 2009). Continuous improvement is a continual effort to enhance the quality of products, to provide better services and to improve processes. This improvement can be step by step improvement or breakthrough at once (Daniels \& Baldrige, 2005).

The relationship of Cost reduction and company's performance with continuous improvement as mediator

The maintenance activities can be grouped into three categories which are reactive or corrective maintenance, preventive maintenance, and predictive maintenance (Heba \& Qiu, 2007) and 
according to (Anup \& Shende, 2011) DMAIC is a closed-loop process, which eliminates those unproductive steps and focuses on new measurements, and applies technology for continuous improvement. Six Sigma reduced error rates, cycle time is shortened, inventory levels are falling, productivity increases, costs reduces, and it provided the profitability with the higher customer satisfaction and increasing of market share (muzaffer, muhammad, \& aihemaituoheti , 2016).

The effectiveness of continuous improvement reduced the number of work cycles, increased product quality, provided cost and time efficiency, ensured profitability and increased market share (Ismyrlis \& Moschidis, 2013) and consequently Green (2006) viewed quality improvement as the aim of Six Sigma, which deliver changes to products and processes that benefit the end user and Rupert \& Peter (2017) refer to prioritizing QI as those that 'reduces the number of quality defects and the overall cost of quality (COQ) of the process'.

The relationship of Elimination of wastages and defects with company's performance having continuous improvement as mediator

Any operation in a process which does not add value to the customer is considered 'waste'. Lean manufacturing is a work environment management philosophy focusing on the reduction or elimination of waste Melton (2005) . According to (Rathje, Boyle, \& Deflorin, 2009) this is how to eliminate the wasteful way of thinking by removing the non-value added processes from the work flow. It also means figuratively tightening the belt in pursuit of increased productivity gains that will increase a company's ability to compete more successfully, while according to Hassan(2013) the efforts to reduce waste, defective products and inventories have increased, improved productivity, customer satisfaction, and superior quality have become increasingly important.

Alves \& Alves (2015) developed a model, and its implementation approach, to integrate sustainability and lean concepts, supported by a cultural transformation. The proposed model 
uses lean techniques and tools to minimise the consumption of natural resources and eliminate wastes and according to Anass, Said, Kannan, Jose, Khalid, \& Ahmed (2017) all the frameworks are based on a continuous improvement culture. The methodologies most applied are PDCA (plan-do-check-act), DMAIC and Kaizen events. Generally, these frameworks start the implementation process by evaluating the current state of the sustainability performance before selecting the right techniques and tools to progress towards sustainability.

\section{RESEARCH METHODOLOGY}

\section{Research Design}

The type of this research is applied because the intention is to have results for the specific criteria in the company as applied research is defined by (Uma, 2003) that research done with the intention of applying the results of the findings to solve specific problems currently being experienced in the organization is called applied research. The method used for this research paper is deductive because it is finding the perceiving for betterment of company performance and moving in top-down manner as according to (Uma et. al.,2003) while giving examples about deduction is that it is the process by which we arrive at a reasoned conclusion by logical generalization of a known fact. For example, we know that all high performers are highly proficient in their jobs. If John is a high performer, we then conclude that he is highly proficient in his job. For concluding the facts and figures, quantitative technique will be used and according to (Williams, 2011) in social science, quantitative research is often used to question relationships between variables. The philosophy of this paper is epistemology because it is developing knowledge about perceiving betterment for company's performance and according to (John, 1999) Epistemology, or theory of knowledge, is driven by two main questions: "What is knowledge?" and "What can we know?" If we think we can know something, as nearly everyone does, then a third main question arises: "How do we know what we do know?" Most of what has been written in epistemology over the ages addresses at least one of these three 
questions. Whereas the stance is positivism because it includes the statistical data for having confirmation about the topic as (Hussey \& Hussey, 1997) state that positivism adopts a scientific stance to research and aims to develop generalized findings from experimentation and structured observations of reality. The research strategy of this paper is survey and we will get response by providing questionnaires preferably in supply chain department and quality department of company within Karachi, Pakistan as (Saunders, Lewis, \& Thornhill, 2012) defines about this research strategy that the survey strategy is typically related with the deductive approach, it is well used in business and management research and is most often used to answer who, what, where, how much and how many questions. Surveys by utilizing questionnaire are common, as they facilitate for the collection of a great amount of data from a sizeable population in an extremely most economical method. The survey sample is usually drawn from a known population and a structured questionnaire is used, and may be complemented with interviews. (Saunders et al., 2012). The choice for collection of data will be mono method as we are collecting data through only one method and according to (Jose \& Roslyn , 2010) the mono method is the study uses only one type of method, one quantitative or one qualitative. In general, in a quantitative study, the data is in numerical form and this information is analyzed using quantitative data analysis techniques. The time horizon of this paper will be cross sectional because the analysis will be done at once as described by (Saunders et al., 2012) the cross-sectional study is that covers a particular phenomenon (or phenomena) at a particular time. The purpose of research is correlational because the mediation is involved in the research and the unit of analysis will be the individuals and the nature of experiment will be field study having the moderate interference of researcher as we have to get response by approaching the respondent and the environment will be non-contrived as described by (Uma et. al., 2003). Whereas the testing will be performed on Smart PLS as the research is having the mediator and the data is primary because according to Ken Kwong 
(2016) this can be configured to perform advanced modeling such as mediator and categorical moderation analysis.

\section{Sampling Design}

The company chosen for the sample is working on Six-Sigma and this is the reason the simple random sampling will be performed because according to (Uma et. al., 2003) when elements in the population have a known chance of being chosen as subjects in the sample, we resort to a probability sampling design. Probability sampling can be either unrestricted (simple random sampling) or restricted (complex probability sampling) in nature. In the unrestricted probability sampling design, more commonly known as simple random sampling, every element in the population has a known and equal chance of being selected as a subject. Let us say there are 1,000 elements in the population, and we need a sample of 100 . Suppose we were to drop pieces of paper in a hat, each bearing the name of one of the elements, and draw 100 of those from the hat with our eyes closed.

\section{Testing}

\section{$\underline{\text { Outer loadings }}$}

\begin{tabular}{|l|l|l|l|l|l|}
\hline & $\begin{array}{l}\text { Quality } \\
\text { Betterment }\end{array}$ & $\begin{array}{l}\text { Cost } \\
\text { Reduction }\end{array}$ & $\begin{array}{l}\text { Eliminating } \\
\text { Wastages \& } \\
\text { Defects }\end{array}$ & $\begin{array}{l}\text { Continuous } \\
\text { Improvement }\end{array}$ & $\begin{array}{l}\text { Company's } \\
\text { Performance }\end{array}$ \\
\hline CI15 & & & & 0.725 & \\
\hline CI16 & & & & 0.831 & \\
\hline CI17 & & & & 0.829 & \\
\hline CI18 & & & & 0.800 & \\
\hline CI19 & & & & 0.721 & \\
\hline CP20 & & & & & 0.708 \\
\hline CP21 & & & & & 0.775 \\
\hline CP22 & & & & & 0.762 \\
\hline CP23 & & & & & 0.728 \\
\hline CR10 & & 0.721 & & & \\
\hline CR6 & & 0.801 & & & \\
\hline CR7 & & 0.820 & & & \\
\hline CR8 & & 0.848 & & & \\
\hline CR9 & & 0.774 & & & \\
\hline EWD11 & & & 0.745 & & \\
\hline
\end{tabular}




\begin{tabular}{|l|l|l|l|l|l|} 
EWD12 & & & 0.802 & & \\
\hline EWD13 & & & 0.811 & & \\
\hline EWD14 & & & 0.764 & & \\
\hline QB1 & 0.715 & & & & \\
\hline QB2 & 0.720 & & & & \\
\hline QB3 & 0.756 & & & & \\
\hline QB4 & 0.742 & & & & \\
\hline QB5 & 0.746 & & & & \\
\hline
\end{tabular}

\section{Quality Criteria}

$\mathbf{R}$ and $\mathbf{R}$ Square

\begin{tabular}{|l|l|l|}
\hline & R Square & R Square Adjusted \\
\hline Company's Performance & 0.372 & 0.366 \\
\hline
\end{tabular}

According to (Cohen-Sawrdlik and Philips, 2013) the value of R-Square should be equal to 0.26 or more than this. The result shows the percentage for the prediction of exogenous variable over endogenous variable and shows the multi co-linearity in the data (Cheah, Memon, Chuah, Ting and Ramayah 2018).

Construct Reliability and Validity

\begin{tabular}{|l|l|l|l|l|}
\hline & $\begin{array}{l}\text { Cronbach's } \\
\text { Alpha }\end{array}$ & rho_A & $\begin{array}{l}\text { Composite } \\
\text { Reliability }\end{array}$ & $\begin{array}{l}\text { Average } \\
\text { Variance } \\
\text { Extracted } \\
\text { (AVE) }\end{array}$ \\
\hline Quality Betterment & 0.757 & 0.762 & 0.837 & 0.508 \\
\hline Cost Reduction & 0.853 & 0.858 & 0.895 & 0.630 \\
\hline Eliminating Wastages \& Defects & 0.738 & 0.755 & 0.835 & 0.562 \\
\hline Continuous Improvement & 0.840 & 0.843 & 0.887 & 0.613 \\
\hline Company's Performance & 0.717 & 0.721 & 0.825 & 0.541 \\
\hline
\end{tabular}

\section{Discriminant Validity}


Fornell-Larcker Criterion

\begin{tabular}{|l|l|l|l|l|l|}
\hline & $\begin{array}{l}\text { Quality } \\
\text { Betterment }\end{array}$ & $\begin{array}{l}\text { Cost } \\
\text { Reduction }\end{array}$ & $\begin{array}{l}\text { Eliminating } \\
\text { Wastages \& } \\
\text { Defects }\end{array}$ & $\begin{array}{l}\text { Continuous } \\
\text { Improvement }\end{array}$ & $\begin{array}{l}\text { Company's } \\
\text { Performance }\end{array}$ \\
\hline Quality Betterment & 0.713 & & & & \\
\hline Cost Reduction & 0.557 & 0.794 & & & \\
\hline $\begin{array}{l}\text { Eliminating } \\
\text { Wastages \& Defects }\end{array}$ & 0.446 & 0.355 & 0.749 & & \\
\hline $\begin{array}{l}\text { Continuous } \\
\text { Improvement }\end{array}$ & 0.510 & 0.498 & 0.450 & 0.783 & \\
\hline $\begin{array}{l}\text { Company's } \\
\text { Performance }\end{array}$ & 0.483 & 0.421 & 0.471 & 0.404 & 0.736 \\
\hline
\end{tabular}

According to (Fornell-Larcker,1981) Discriminant validity means that a latent variable is able to account for more variance in the observed variables associated with it than :

a) Measurement error or similar external, unmeasured influences.

b) Other constructs within the conceptual framework. If this is not the case, then the validity of the individual indicators and of the construct is questionable.

As suggested by the Haier et al $(2013 ; 2014)$ that any value greater than 0.7 considered at the acceptable value for the reliability.

\section{Total Effects}

\begin{tabular}{|c|c|c|c|c|c|}
\hline & $\begin{array}{l}\text { Original } \\
\text { Sample (O) }\end{array}$ & $\begin{array}{l}\text { Sample } \\
\text { Mean (M) }\end{array}$ & $\begin{array}{l}\text { Standard Deviation } \\
\text { (STDEV) }\end{array}$ & $\begin{array}{l}\text { T } \quad \text { Statistics } \\
(\mid \text { O/STDEV } \mid)\end{array}$ & $\begin{array}{l}\mathbf{P} \\
\text { Value } \\
\text { s }\end{array}$ \\
\hline $\begin{array}{ll}\text { QB } & -> \\
\text { CI } & \end{array}$ & 0.251 & 0.251 & 0.069 & 3.656 & 0.000 \\
\hline $\begin{array}{ll}\text { QB } & -> \\
\text { CP } & \end{array}$ & 0.255 & 0.259 & 0.066 & 3.867 & 0.000 \\
\hline $\begin{array}{ll}\text { CR } & -> \\
\text { CI } & \end{array}$ & 0.272 & 0.276 & 0.060 & 4.516 & 0.000 \\
\hline $\begin{array}{ll}\text { CR } & -> \\
\text { CP } & \end{array}$ & 0.174 & 0.172 & 0.059 & 2.954 & 0.003 \\
\hline $\begin{array}{l}\text { EWD -> } \\
\text { CI }\end{array}$ & 0.242 & 0.241 & 0.062 & 3.911 & 0.000 \\
\hline $\begin{array}{l}\text { EWD -> } \\
\text { CP }\end{array}$ & 0.295 & 0.296 & 0.060 & 4.884 & 0.000 \\
\hline $\begin{array}{ll}\text { CI } & -> \\
\text { CP }\end{array}$ & 0.087 & 0.081 & 0.078 & 1.117 & 0.264 \\
\hline
\end{tabular}

In this table all $\mathrm{P}$ is lower than 0.05 and the other side all $\mathrm{T}$ values are greater than 1.97 .It means all the Null hypothesis we construct in this paper are rejected. According to the found 
results all null hypothesis are rejected that's means the strong relationship exist between and Company's performance and quality betterment, Cost reduction if the mediator (continuous Improvement) is available.

\section{CONCLUSION}

This paper indicates that the performance of the company becomes highly reliable, reduced cost, eliminate wastages and improve quality by the adaption of Six-Sigma practices. The study is also reported that the continuous improvement is also playing a mediating role when we consider Company's performance as dependent variable and cost reduction, Quality betterment and eliminate wastages as independent variables. The results shows that the independent variables have a positive effect on dependent variable when the mediator is existing between them. The conclusion is based on the statistical results shown above with complete references. 


\section{REFERENCES}

Alves, J. R., \& Alves, J. M. (2015). Production Management Model Integrating the Principles of Lean Manufacturing and Sustainability Supported by the Cultural Transformation of a Company. International Journal of Production Research, 51(11), 1-14.

Anand, G., Ward, P. T., Tatikonda, M. V., \& Schilling, D. A. (2009). Dynamic capabilities through continuous improvement infrastructure. Journal of Operations Management, 27(6), 444-461.

Anass, C., Said , E., Kannan , G., Jose , A. G.-R., Khalid , B., \& Ahmed , M. (2017). A framework for the integration of Green and Lean Six Sigma for superior sustainability performance. International Journal of Production Research, 55(15), 4481-4515.

Anup, A. A., \& Shende, P. N. (2011). Minimization of Rewok In Belt Industry Using Dmaic. International Journal of Applied Research in Mechanical Engineering, 1(1), 54.

Ayon, C., \& Michael , L. (2013). Developing a Six Sigma framework: perspectives from financial service companies. International Journal of Quality \& Reliability Management, 30(3), 256-279.

Basant , C., Dixit , G., \& Ashish , A. (2019). Lean Six Sigma approach: a strategy to enhance performance of first through time and scrap reduction in an automotive industry. Int. J. Business Excellence, 42-57.

Bhutta, K., Egilmez, G., Chatha, K., \& Huq, F. (2017). Survey of Lean management practices in Pakistani industrial sectors.

Chang, T. I. (2002). Six Sigma: a framework for small and medium sized enterprises to achieve total quality. Ohio,USA: Unpublished doctoral dissertation.

Daniela , S. L., \& Marly , M. C. (2016). Critical success factors for Six Sigma projects. International Journal of Project Management, 1505-1518.

Daniels, S. E., \& Baldrige, M. (2005). National quality award. Quality Progress, 38(6), 54-62. 
Evans, J. R., \& Lindsay, W. M. (2008). Managing for quality and performance excellence. The Management and control of quality. Cincinnati.

Gluckman, A. (2003, September). "Quality in, workers out? Companies adopt Six-Sigma,". 1517.

Green, F. B. (2006). Six-Sigma and the revival of TQM. Total Quality Management and Business, 1281-1286.

Grey , C. (2019). Grey Campus- Global Network for high quality instructors. Retrieved November 18, 2019, from Grey Campus: https://www.greycampus.com/opencampus/lean-six-sigma-green-belt/history-of-sixsigma

Hassan, Muhammad M., "The Prevalence of Six Sigma Trends in the Construction Industry in Pakistan" (2017).Masters Theses \& Specialist Projects.Paper 2019

Helfat. C. E., Finkelstein, S., Mitchell, W., Peteraf, M. A., Singh, H., Teece. D.J., Winter, S. G., 2007. Dynamic Capabilities: Understanding Strategic Change in organizations. Blackwell Publishing, Malden, M.A.

Heba, A., \& Qiu, X. (2007). A Model For Assessing Cost Effectiveness of Applying Lean Tools. Växjö University.

Heuvel, J., Does, R., \& Bisgaard, S. (2005, Feb). “Dutch hospital implements Six Sigma”. 1114. ASQ Six Sigma Forum Magazine.

Hussey, J., \& Hussey, R. (1997). Business Research: A Practical Guide for Undergraduate and Postgraduate Students. Basingstoke: Macmillan Press Ltd.

Ismyrlis, V., \& Moschidis, O. (2013). Six Sigma's critical success factors and toolbox. International Journal of Lean Six Sigma, 4(2), 108-117.

John, G. (1999). Introduction: What is Epistemology? The Blackwell Guide to Epistemology, pp. 1-31. 
Jones, S. (2004). Understanding Six Sigma. 43(3), p. 24.

Jose, M. A., \& Roslyn , C. (2010). The Application of Mixed Methods in Organisational Research: A Literature Review. Electronic Journal of Business Research Methods, 95105.

Judita , N., \& Aurelija , U. (2018). COMPARATIVE ANALYSIS OF COMPANY PERFORMANCE EVALUATION METHODS. The International Journal ENTREPRENEURSHIP AND SUSTAINABILITY ISSUES, 6(1), 125-138.

Ken Kwong, K. W. (2016). TECHNICAL NOTE: Mediation analysis, categorical moderation analysis, and higher-order constructs modeling in Partial Least Squares Structural Equation Modeling (PLS-SEM): A B2B Example using SmartPLS. Retrieved November 11, 2019, from Research Gate: https://www.researchgate.net/profile/Ken_Wong10/publication/303402222_TECHNI CAL_NOTE_Mediation_analysis_categorical_moderation_analysis_and_higherorder_constructs_modeling_in_Partial_Least_Squares_Structural_Equation_Modeling _PLS-SEM_A_B2B_Example_using_

Kun-, C. L., Honglei, L., \& Bong, C. (2011). A Theoretical Framework for Exploring the Effect of the Six Sigma Management Activities on Corporate Competitiveness. Proceedings of the Seventeenth Americas Conference on Information Systems. Michigan: AIS Electronic Library (AISeL).

Mason, S., Nicolay, C., \& Darzi, A. (2015). The use of lean and Six-Sigma methodologies in surgery:a systematic review. The Surgeon: Journal of the Royal Colleges of Surgeons of Edinburgh and Ireland, 13(2), 91-100.

Mohamed, K. H. (2013). Applying Lean Six Sigma for Waste Reduction in a Manufacturing Environment. American Journal of Industrial Engineering, 1(2), 28-35. 
Muzaffer, E., Muhammad, A. T., \& AIHEMAITUOHETI , W. (2016). The Effects of Six Sigma Approach on Business Performance: A Study of White Goods (home appliances) Sector in Turkey. 5th International Conference on Leadership, Technology, Innovation and Business Management (pp. 444-452). Elsevier Ltd.

Nilesh, V. F., Bansod, D. V., \& Swati, N. F. (2012). Understanding the benefits and limitations of Six-Sigma methodology. International Journal of scientific and research publications, 2(1), 331-339.

Pearson.(2019).Retrievedfromhttp://www.informit.com/articles/article.aspx ?p=457313\&seqN $\mathrm{um}=3$

Pfeifer, T., Reissiger, W., \& Canales, C. (2004). Integrating Six Sigma with quality management systems. The TQM Magazine, 16(4), 241-249.

Piercy, N., \& Rich, N. (2009). Lean transformation in the pure service environment: the case of call service centre. International Journal of Operations \& Production Management, 29(1), 54-76.

Prybutok, V. R., \& Ramasesh, R. V. (2005). An action-research based instrument for monitoring continuous quality improvemen. European Journal of Operational Research, 166(2), 293-309.

Quality Gurus. (2019). Retrieved from https://www.qualitygurus.com/history-of-six-sigma.

Rathje, M. S., Boyle, T. A., \& Deflorin, P. (2009). Lean take two Reflections from the second attempt at Lean implementation. Business Horizons, 52, 79-88.

Rupert, L. M., \& Peter, E. M. (2017). Continuous, quality and process improvement: disintegrating and reintegrating operational movement? Total Quality Management \& Busniess Excellence, 28(3-4), 296-317.

Saunders, M., Lewis, P., \& Thornhill, A. (2012). Research Methods for Business Students (6 ed.). Pearson. 
SBF. (2013). Construction Opportunities \& Doing Business in Pakistan. Retrieved from High Commission of Pakistan,Singapore: http://www.mofa.gov.pk/singapore/documents/BCA-Pakistan-High-Commission

Staatsa, B. R., Brunnerb, D. J., \& Upton, D. M. (2011). "Lean Principles, Learning, and Knowledge Work: Evidence from a Software Services Provider. Journal of Operations Management, 29, 376-390.

T., M. (2005). The Benefits of Lean Manufacturing What Lean Thinking has to Offer the Process Industries. Chemical Engineering Research and Design, 83(A6), 662-673.

Uma, S. (2003). Research Methods for business (4th ed.). Newyork: Malloy Lithographing, Inc.

Williams, C. (2011). Research methods. Journal of Business \& Economics Research (JBER), $5(3), 25-32$.

Zhang, M., Wang, M., Goh, T. N., \& He, Z. (2015). Comprehensive Six Sigma application: a case study. Production Planning and Control, 26(3), 219-234. 